\title{
EXOTIC PRIMITIVISM OF DEATH IN CLASSICAL HOLLYWOOD LIVING DEAD FILMS
}

\author{
Outi Hakola \\ University of Helsinki
}

\begin{abstract}
The classical Hollywood horror exhibited the undead monsters, such as mummies, zombies and vampires, at the time when cultural practices of death and dying were changing in the United States. Consequently, the way death is handled in these films is connected to the ongoing marginalization of death. In the classical films, heroes represent modern, medicalized, scientific and marginalized death. In contrast, the undead represent traditional, or irrational and magical, death. When the heroes hunt down and kill the monsters, they also claim the superiority of modern death. Furthermore, the exclusion of traditional death is highlighted by using (post)colonial tensions. The non-western monsters and realm of the world stand for traditional death and the past whereas western heroes represent modern death and the future. This article concentrates on how the classical living dead films narrate the cultural tension between the waning (traditional) and emerging (modern) practices of death.
\end{abstract}

Keywords: Classical Hollywood, Death, Living Dead, Horror Films, Colonization.

\begin{tabular}{|l|l|l|l|l|}
\hline Ilha do Desterro & Florianópolis & $n^{\circ} 62$ & p. 219- 240 & jan/jun 2012 \\
\hline
\end{tabular}




\section{Introduction}

Mummies, zombies, vampires and other living dead characters made their way into classical Hollywood films in the early 1930s, soaking the horror genre in an all-encompassing presence of death. The undead monsters embody death; death events are used as main narrative turning points; and death has both aesthetic and metaphoric dimensions. The close relationship between death and the living dead films carries on the western imagination of fear in folk stories for the returning dead as destructive forces and carriers of death and dying. Despite their rather universal and ahistorical theme, the living dead stories approach the omnipresent death in various ways in different eras. In this article, I will study three living dead films of classical Hollywood-Tod Browning's Dracula (1931), Karl Freund's The Mummy (1932), and Victor Halperin's White Zombie (1932)and their understanding of death in the cultural context of early twentieth-century United States.

The success of Dracula by the Universal Studios made horror production a popular part of early 1930s Hollywood. At the same time, in the United States, practices of modern death were taking shape. As Thomas Schatz argues, the "success of any genre depends upon at least two factors: the thematic appeal and significance of the conflicts it repeatedly addresses and its flexibility in adjusting to the audience's and filmmaker's changing attitudes toward these conflicts" (31). In the classical living dead films, repeated death-related conflicts are connected to the changing cultural practices of death and dying. Modern death thus provided a starting point and the socio-cultural context for these films' understanding of death.

Modern death can be defined as a tendency to marginalize death. A number of scholars, Philippe Ariés, Norbert Elias, and 
Zygmunt Bauman among them, have suggested that with the onset of modernization, industrialization, and medicalization, death and the dying have slowly been marginalized and removed into hospitals and other specialized institutions to be dealt with by professionals. This process has taken death away from the social sphere, replacing the public experience of death with experiences of the private.

The ideals of modern death had been in the making since the late eighteenth century, after the Age of Enlightenment had promoted science and knowledge as the basis for the society. Similar values came related to attitudes towards death, but it was the early twentieth century that saw the rapid professionalization of death in practice. In the United States, it took until the mid-century for the majority of deaths to move from homes to hospitals. In the 1930s, remnants of old death-related practices still coexisted with modern ideals. The classical living dead films narrate this tension between the waning and the emerging attitudes and practices, creating conflict between modern and traditional death.

Traditional death, according to Tony Walter, was quick and frequent, an open part of a community's life, and managed by priests and religious rituals (47). In the living dead films, heroes represent the scientific approach to death, whereas monsters are the embodiment of the magical or the religious aspects of traditional death. In the formulaic narration of classical monster stories, the monsters are hunted down and killed by the heroes. This translates into the exclusion of the undead monsters from the society in the living dead films, which ultimately confirms the superiority of modern death over the traditional.

The living dead films' myths and ideologies that go together with this confirmation of dominating ideals are not unproblematic or straightforward. Although the change from traditional to modern death was taking place within American culture and society, in 
the classical films the conflict is externalized outside the United States. The classical living dead films portray American modernity as ideologically consistent: The western realm of the world and the United States are seen as representing modern society and modern death. In contrast, the non-western world is made to stand for traditional death and the past. The exclusion of traditional death from the modern United States is highlighted by the use of foreign monsters and landscapes. Vampires come from marginalized Eastern Europe, mummies from ancient Egypt and zombies from Caribbean islands. In the horror narrations, western characters, as representatives of the modern death, face threat from the undead figures, or the traditional death. When the conflict between two death-related practices is presented through different cultural spheres, the very theme of death becomes intertwined with questions and practices of the (post) colonial world.

Therefore, I will discuss the problematic relationship the American classical living dead films have with other cultures. The cultural conflict is intriguing because since World War I, Hollywood (including its horror films) has had a leading position in the western film market and a strong foothold in other parts of the world. Similarly, Hollywood's horror cinema has brought together an international gothic culture and the needs of the American national cinema. For example, classical Hollywood horror borrowed the aesthetic influences of German expressionism and pre-existing horror stories from different cultures, collecting film-makers, screen writers, actors and shooting locations from different parts of the world.

Hollywood also aimed its products at both national and international audiences. David Bordwell, Janet Staiger and Kristin Thompson argue that classical Hollywood producers directed their films to a wide audience across nations and diverse backgrounds 
(4-13). The classical films managed to gather wide audiences despite differences in languages, nationalities, districts or class. For example, universal themes, such as death or love were used to address all audiences. However, the actual audiences were never homogenous and even the American audiences were a mix of different ethnic, national and cultural backgrounds.

According to Barry Keith Grant, when classical Hollywood repeated the same story lines and themes time after time, the formulaic genre films started to function as an ideal melting pot where the understandings of American culture were transmitted and transformed (5). Similarly, the living dead films, although internationally oriented in production and marketing, participate in reinforcing American death-related values, attitudes and practices at the content level. And, at the content level, the tension is created between international and national dimensions of the stories

\section{Horrifying death in living dead films}

The process where American death-related values are formulated within the living dead films is also generic. Deaths in living dead films do not reflect or directly imitate the everyday reality of viewers; what they offer instead are dramatic, narrated and generic spectacles. The horror genre, in particular, encourages the contribution to shocking and culturally controversial issues, which is why the genre conventions frame death in a dystopic manner, representing it as unnatural, disturbing and violent.

Steve Neale argues that because even the most formulaic story can only repeat a certain amount of all possible conventions, every genre has a dominant feature which defines the genre at a basic and descriptive level (220). The horror genre can be delimited by its 
intentions: a horror film aims to cause horror in the viewer (and does what it set out to do). To fulfill this affective intention, many horror films depend on the monster centrality. For example, in Noël Carroll's influential horror identification theory, horror is marked by the characters' emotions towards the monster. Quite plainly, horror seeks to horrify the viewer, and the ways in which the fictive characters react to the monster mediate the appropriate emotion for the horror genrehorror, terror and disgust - to the viewer (Carroll 16-17, 60-86).

Not all horror films depend on the existence of a monster, but the living dead films appear to do so. They all have central monsters, such as vampires, mummies and zombies, who create a threat which calls for other characters' reactions. The films start with recognizing the monsters and their undead state. For example, the horrified locals in Dracula are frightened by the vampires because "they (vampires) leave their coffins at night". In White Zombie, the local driver who is startled by the zombies argues that "they are not men, they are dead bodies". And in The Mummy, even the western archeologists flinch at the curse attached to the mummy's casket: "Imhotep was sentenced to death not only in this world, but in the next." These reactions and recognitions spotlight the monstrousness of walking corpses and mediate the fear and cringing at the undead state.

Indeed, the living dead characters are defined through their unnatural relationship with death. Although there are multiple and varied cinematic characters with problematic relationship to dying and death, some limits can be set for the living dead. For example, Richard Greene and K. Silem Mohammed define them as "corporeal beings who are physically or mentally dead, but are in some way not 'at rest"' (xiv). The living dead are left in the liminal state between the two stable states in which a person is first a mortal and then a buried dead. Because the living dead refuse to stay in their marginalized and 
sanitary positions in graves and mortuaries, they become connected with chaos and impurity, thus destabilizing the existing social order.

In other words, the transgressing and anarchic state of the living dead threatens and confuses prevailing cultural categories. In her influential book Purity and Danger, anthropologist Mary Douglas discusses the now commonly adopted perspective that cultures are built on different regulations, rules and categories. These rules give order and system to the society, making filth and sickness, for example, abnormal because they threaten the order of society and create possible chaos. The conservation of categories through cleanliness, for example, becomes a sign of maintaining social order (Douglas). Similarly, because the living dead defy "normal" death rites and the process of dying, they become ritually impure.

At the same time, they fulfill the generic task of horror, where "monster threatens normality", as famously defined by Robin Wood. He continues, "although so simple, the formula provides three variables: normality, the Monster, and, crucially, the relationship between the two" (Wood 175, 176). When the living dead characters are recognized as monsters, the classical films also mark the traditional death they symbolize with otherness. In consequence, because the monsters denote the necessary affections, horror and terror, traditional death, too, becomes marked as horrifying and terrifying. Indeed, the classical film narration dehumanizes the living dead and their problematic relationship to death at a time when death was becoming socio-culturally marginalized from the public. Norbert Elias, for example, connects the rejection of death with a civilization process which has slowly repressed all signs of animality, including death, from culture and society (13-18). Compared to modern death, the traditional death represents the past and more primitive state of civilization. 
Animality becomes flesh in the corporeality of the bodies of the living dead. Vampires, mummies and zombies personify death, not through symbolic elements, but because they are preserved corpses that make death visible. In this way, they oppose the modernization process, which shifted away from bodily processes towards control executed through knowledge. In their corporeality, the living dead embody those parts of humanity which already seem under control in modern western society. Furthermore, their magical relationship to death contrasts and challenges the scientific understanding of death.

The scientific or modern view is also contrasted by the primitive and pagan themes. In White Zombie, bokors (priests) have power to create zombies with voodoo magic. Bokor traps the victim's soul, and postmortem bodies keep walking around with a catatonic face without memories and ability to speak or to recognize anyone. White Zombie marks Haitian voodoo as superstitious when Legendre, the zombie master, uses dark magic on his victims.

The connection to pagan primitivism is especially clear in The Mummy. The mummy, alias Imhotep/Ardath Bey, is an ancient priest and expert of death rituals. In the classical films, his expertise is marked with the unknown and the primitive, although in ancient Egypt mummies were part of a rich death system and religious structures, where the scientific preservation of the body was an important element of spiritual afterlife. However, when the classical film was made, the scientific procedure of mummification was partly unknown. Instead, the popular mysticism of the early $1900 \mathrm{~s}$ concentrated on the exoticism of the ancient burial practices and the rumors of the mummy's curse, fed by the discovery of Tutankhamun's almost intact tomb in 1922. If not before, the horror films shifted the popular interest into a monstrous direction. Jasmin Day claims that when it endowed the horror genre with the mummy, Hollywood 
transformed the mummies of ancient Egypt into mythological and pagan demons $(2-9,170-173)$.

In the case of vampires, too, Hollywood chose to concentrate on the demonic storyline. Instead of going after more romantic gothic fiction, such as John William Polidori's The Vampyre (1819) or Joseph Sheridan Le Fanu's Carmilla (1872), Hollywood focused on Bram Stoker's Dracula (1897). Benson Saler and Charles A. Ziegler argue that Stoker's novel was conveniently structured as a monsterslaying story with cathartic possibilities. The openly monstrous and magical figure of Transylvanian Dracula therefore fit easily into Hollywood horror and its understanding of monster stories (Saler \& Ziegler 17-19). In this context, despite the deceivingly civilized appearance, Dracula is marked as a devil figure whose animality is further stressed by his capability to turn himself into a bat or a wolf.

Pagan religiosity, corporeality and animality are connected to a primitivism which highlights the otherness of the living dead to modern society, and the otherness of other cultures to the United States. The monsters represent other and more primitive cultures, and the films open with western characters traveling to exotic locations and encountering that which is uncivilized. For example, in White Zombie a young couple, Madeline and Neil, have arrived in Haiti in order to get married. During the opening credits, a local funeral serves as a visual and audio background. It is already dark, and the workers are heard chanting rhythmically while they are filling a grave. The darkness, low lighting and what looks like an exotic ritual from a western perspective create an atmospheric setting. The impression of primitive superstition is highlighted through the local funerary habits where the corpse is buried in the middle of the road to be better guarded against the evil forces which might take advantage of the corpses. Kyle Bishop argues that such use of landscapes-foreign 
castles, ancient settings and romanticized lands-gives films a Gothic stylization, but it also accentuates their remoteness from American culture (144).

Robin Wood claims that this externalization can be interpreted in two ways. Either these films are highlighting horror as un-American or the exotic countries represent the general psychological state of humanity (Wood 172, 183). I argue that both of these tendencies are present in the classical living dead films. The exotic countries and locations come to represent the past, traditional and non-modern societies, and thus the less civilized form of humanity. In contrast, the western characters and the United States represent the future and modern society. By emphasizing the foreign and terrifying roots and nature of the undead characters, these films seek to exclude and marginalize death from the American experience.

\section{Monstrous Colonization}

When the traditional death stays in its own cultural context of the past or the primitive, it is not threatening, but rather superstitious from the western perspective. For example, when the local people try to warn Renfield about Dracula and his wives- "They leave their coffins at night and they feed on the blood of the living," Renfield dismisses the warnings:- “Oh, but that's all superstition". And, in White Zombie, after they have been warned about the zombies, Neil and Madeline dismiss the local beliefs by remarking to a western missionary "Surely you don't believe them".

The primitivism and paganism of The Mummy are made visible to the viewer through ancient Egyptian funeral rites, repeated twice in the narration. First, they are shown as a memorial of an ancient Egypt. In this scene, the rituals of embalming and burial are mystified: 
they are fascinating and horrifying at the same time, and they can be accepted as part of a mystical past of a primeval religion. However, when the resurrected mummy wants to re-enact the ancient rituals in the modern world and change Helen, the female protagonist, into his mummified princess, the same rituals become outmoded, unacceptable and terrifying. While Helen is possessed by the spirit of an ancient princess, she still recognizes the shame in the old rituals. She argues to the mummy "I loved you once, but now you belong with the dead. I am Anck-es-en-Amon, but I'm somebody else, too. I want to live, even in this strange new world".

In the classical films, then, traditional death can be accepted as part of the past or non-western, and thus, uncivilized worlds. However, it becomes a threat and a problem, when there is a link to the modern and western world. The western characters do not care if Dracula kills the local people of Transylvania, or if voodoo priest Legendre zombifies local workmen into his slaves, or if mummification rites were used in ancient Egypt. It is when the undeadness threatens to consume the western realm of the world that the monstrousness of vampires, mummies, zombies and zombie masters becomes legitimized, and the American realm of the world might be colonized.

The threat of such colonization is foregrounded by the consuming and contaminating nature of the undead bodies. Although the consumption theme is more visible in the recent living dead films, the vampires, mummies and zombies of the classical era already have needs such as hunger or sexual urges. As Phillip Cole puts it, we are not scared of the undead only because we fear death, but we are afraid of the dead who come back to destroy and consume us (186-188). In addition, the living dead often have the power to change us. For example, vampires contaminate their victims by sucking their blood. 
As Margrit Shildrick argues, the monstrous body is anomalous also because it carries a risk of contamination-if not at the material level, conceptually at least, because the improper body threatens to reveal the constructed nature of the "proper" bodies (68-73). Contamination in the living dead films is also conceptual as the possible colonization of the traditional death reveals the constructed nature of the modern death.

Fear of monstrous colonization works at the narrative level of the classical films, but in addition it uses existing (post)colonial relations. The Mummy was filmed when Egypt was slowly gaining independence from Britain. The growing demand for self-governance and sporadic hostility against the former colonial masters threatened the western position. Prior mummy novels, Jasmin Day argues, were an expression of guilt over western colonialism, making the mummies' revenge just because they were repelling against an external sovereign. Symbolically, the changed political situation turned mummies into a threat and transformed the mummy legends from the domain of justified revenge to a threat for the autonomy of western characters (Day 21, 8-9, 50, 81).

White Zombie was produced when US occupation of Haiti (1915-1934) was nearing its end. Mimi Sheller, Edna Aizenberg, and Kyle Bishop, for example, argue that instead of telling about their own history of slavery, the Haitian voodoo zombies are important allegories of US occupation of the country (Sheller 146, Aizenberg 462, Bishop 145). When the occupation ended, the colonizing models of economic and political power were adopted by the local elite. Similarly, in White Zombie, the film's monster Legendre, a local voodoo master, enslaves his own countrymen and makes them automated zombies who are forced to obey their master, without a free will of their own. The classical zombies thus become connected 
to questions of exploitation of power and loss of autonomy (Sheller 145). Later on, Legendre tries to dominate the western characters as well, and in this way, the possibility of automated zombies starts to threaten the individualized American culture.

Dracula's connection to colonization is constructed through the immigration theme. Dracula travels to London where his otherness becomes obvious and similar to the colonization threat. Kendall Phillips maintains that Dracula is "dramatically foreign" with his foreign accent and eccentric mannerism. He represents an invasive and foreign chaos created by European immigrants arriving in the United States (23-31). In all three cases, the narrative conflict is created when the non-western countries suddenly turn the direction of the colonizing process. At this point, they and the values they represent become a threat to western civilization and modern values.

In the classical living dead films, the colonizing threat is acted out through the characters. Richard Dyer argues that in western thinking and cinematic practices, whiteness is connected to normality and humanity whereas other races are made to represent themselves (223). Similarly, in Dracula, White Zombie and The Mummy the white western characters symbolize normality whereas the threatening monsters are external to the white race and/or the western world. The racial and ethnic dimensions of a colonizing threat are thus made visible and are used to highlight the primitivism of both the monsters and the traditional death.

This racial and primitive threat of colonization is emphasized through the use of the western victims. For example, in White Zombie Legendre, the local voodoo priest, zombifies a young, white western woman, Madeline. Her fate becomes central to the film, because the problems of zombification have remained marginal and local, but when Madeline is threatened, the monster threatens 
to contaminate the American realm of the world. Or as Phillip Cole articulates, the monsters threaten "our territory, our culture, our identity" (192). This threat of colonization and consumption is highlighted by a racial question of the primitive bodies. Bishop argues that the major threat in White Zombie is hybridization of western cultural purity by a primitive culture. When the white protagonist is in danger of becoming an enslaved zombie under the natives' command, she might be colonized. And as Madeline's fiancé Neil comments, "Better dead than that" (Bishop 141-145, 150). Indeed, in this film white bodies become vulnerable not only to death, but of an infectious threat to hybridization between races. In such an equation, as Edna Aizenberg and Mimi Sheller argue, the Haitian bodies are connected to barbarism, animality and immorality (Aizenberg 462, Sheller 146, 152).

Furthermore, the colonization threat of the classical films is not only racial but gendered as well. Whereas the racial connection is used to mark the traditional death as primitive, the use of female victims relates to gendered death-related practices. According to Tony Walter, women have historically carried the responsibility for mourning and reacting to death (18). Similarly, in classical Hollywood horror, in general, women were used as victims whose most important function was to mark the horror and terror. Women in the living dead films are at the same time marking the traditional death as horrifying and they are more open to it because of their narrative and cultural role of embracing the emotional rather than the rational.

Women are both fascinated and terrified by the undead monsters. This is highlighted by the erotized nature of the monsters. In the living dead films, all main monsters, Dracula, Imhotep and Legendre, desire a romantic relationship with 
western women. While all these monsters use their hypnotic powers to seduce their lovers, the possession of women is not merely violent. The women in The Mummy and Dracula, in particular, also desire the monstrous otherness, and the vampire film is especially keen to use desire as an essential part of its story. Dracula seduces and violates bodily boundaries, and is overloaded with an erotic imagery. His victims are mostly women, including Lucy and Mina, and he plans to transform them into his wives. The women, too, are fascinated by the vampire, who enables a free expression of sexuality. For example, after Mina has been kissed by Dracula, she claims: "I love the night. Why, it's the only time I feel really alive." Death can therefore be empowering from the women's perspective, because it can liberate them from controlled social rules, as in the case of sexuality.

In The Mummy, Helen is caught in a triangle of a love affair in falling in love with Frank while being fascinated by Imhotep. She describes her desire to live in both the modern and ancient worlds: "There's death there for me. And life for something else inside me that isn't me. But it's alive too, and fighting for life". The attempted colonization of traditional and supposedly more intimate death is also a source of fascination for her. Through the women characters, the colonization of the undead is also about the desire to return to an intimate and close relationship to death. For example, Bishop argues that in the mists of the modernization process the primitive cultures became an escape to "simplicities of the past", no matter how imaginary these traditional worlds were (Bishop 144).

All in all, the traditional death of the classical living dead films is a threat to a modern understanding of death, not only conceptually, but because of its colonizing powers. These powers are presented through western women. They symbolize the weaknesses of modern 
society which occasionally desires a return to a more "simple" or "primitive" state of the death-related practices. And yet, the (racial) primitivism is recognized as threatening. The colonization threat towards white and western women makes the practices of nonwestern cultures problematic, which launches the resistance of western men, who line up against oppression.

\section{Resolution: recontrolling death}

From the western perspective, both the liminal state of the undead and the possibility for colonization need to be solved. This follows the basic monster narration which, according to Carroll, can be simplified into a story of revelation and exposure. It is here that the monster can be encountered and destroyed (97-108). Similarly, in the living dead films, after the liminal states of the Count Dracula and Imhotep as well as the hypnotic powers of Murder Legendre are revealed, the encounter with and destruction of the monsters becomes possible. This destruction is also about re-controlling the (traditional) death they represent.

The undead who defy the limits of death stand for the failure of societal control by refusing to be placed in accepted positions. For example, the mummy is able to rise from his tomb because the insufficient primitive rituals have not sanctified his body enough, but have left him in a primitive, impure, and uncontrolled state. As a punishment of his earlier crimes, the Egyptians had cursed him to a liminal state. From the western perspective, the inbetweenness wants resolving. The mummy, as well as the undead status of vampires and zombies, needs to be re-controlled by killing and burying these bodies through western rituals. 
The means of re-controlling death are primarily scientific. In the films, the task of re-regulating has been given to the scientific and medical authorities, such as Doctor Van Helsing, Doctor Muller, and Missionary Burner, who represent social control, knowledge, and power. Furthermore, whereas western women represented the victims, western heroes are played by men. This correlates with Tony Walter's notion that when death was modernized, it was also masculinized: the death industry of doctors, funeral directors, police officers, soldiers, etc. used to be controlled by men (13). Similarly, men in the classical living dead films stand for a modern and scientific approach. The male characters become the authoritative and rational voices that keep death at bay.

In this process, women become objects in the battle of male dominion between uncivilized monsters and civilized western heroes, between traditional and modern death. In these films, women become possessed by men. For example, Edward Lowry and Richard deCordova see the male characters' relationship to Madeline as possessive: first she is possessed by her fiancé, then by the monster(s), and in the end, when the romantic couple is reunited, the fiancé regains his possession (351).

Similarly, in Dracula, the narrative tension is built on the interaction between Dracula and Van Helsing, who struggle over the dominant position. In the struggle, the victims, Lucy and Mina, are reduced to being assistants in the story, objects in a conflict between two strong men who are more interested in proving their cases and powers than saving or seducing the victims. In the end, Van Helsing tracks the vampire down and kills him. On an allegorical level, then, Van Helsing comes to represent modern death, fighting for its cultural power over the non-scientific, unexplainable death of Dracula. 
In the classical living dead films, the scientific authorities either kill the monster or provide necessary information for this victory. However, they decline to take responsibility for the emotional encounter of death, such as mourning or loss. Instead, the authorities who represent public institutions create an explanation and solution for the existence of the undead monsters, but they channel the emotional part of the encounter to the private persons. For this purpose, all the classical films also have romantic heroes to represent the private sphere and interpersonal relationships. The romantic leads, such as John, Neil and Frank, recognize the need to save their women from the traditional death and in the process they listen to the authorities and allow them to kill the monsters.

Instead of actively distancing death, the romantic leads take responsibility for emotional reactions. They recover the women for the western realm. John carries Mina away from the vampire's tomb to the sunrise. Neil calls for Madeline's soul to return to her zombified body. Even in The Mummy, where Helen is the one who kills the mummy, Frank is seen as a savior who calls her soul back from the ancient world. Even if the women had succumbed to the monsters and traditional death, the romantic leads who signify normative heterosexuality manage to restore the normal state of modern and western society. The solution suggests that it is not enough that the medical and public institutions take responsibility over death in the modern societies, but these practices need to be accepted and generalized in the everyday practices of the citizens. 


\section{Conclusion}

The scientific systems of the west have sought to explain death. This process also takes place in the classical films in which western characters encounter the undead, who represent a magical understanding of death. In these films, the irrational undead and the concept of traditional death are explored, removed and displaced with the rational and the modern death. Although (traditional) death is visible throughout the narration on several levels, the role of death is silenced in the end. The women, who have had a direct relationship with the traditional death, seem to forget their experiences. Instead, they wake up as from a long dream. For example, when Madeline's consciousness returns, she smiles "Nils, I dreamed". The experiences of traditional death are not allowed to become part of the modern society even as memories, but instead they are silenced and confined to the dream world.

Furthermore, the constant tension between modern and primitive becomes a tension between western and non-western. In the classical living dead films, the western people are always victorious. Even though the local people suffer in the hands of the monsters, they seem to accept the magical existence of the undead as part of the world. It is the "rational" western people who provide the resistance when needed.

For example, after Legendre has zombified several local people in White Zombie, his mistake is to zombify a western man, Beaumont. He becomes the first man to resist the suppressing power. Through his knowledge of the voodoo practice, he confronts the zombie master and drags him to death. The white man prevails and stands against oppression, while the Haitian slaves remain unconscious and follow their master to death. Bishop quite rightly argues that the colonial 
zombies remain as uncivilized others who have no place in the western order. When the zombies are finally heard, it is rather recognition than true interaction from the westerners (Bishop 147, 150).

In the films, communities change, too. The western characters of Dracula, White Zombie, and The Mummy release not only themselves but also the local roots of the monster from the primitive powers. However, the films pay scant respect to the needs and desires of the local communities, preferring instead to prove western and American supremacy and the importance of the civilization project.

Indeed, when the classical living dead films are read through death-related symbolism, the western characters modernize the world where other countries represent the primitive. And when traditional death meets the western realm, the western characters replay the modern alienation of death by following scientific procedures and using rational knowledge against pagan religion. In the end, western practices emerge as superior: the modern, civilized, and medicalized death overcomes the death of the traditional, religious, and pagan world.

\section{References}

Aizenberg, Edna. "I Walked with a Zombie.' The Pleasures and Perils of Postcolonial Hybridity”. World Literature Today, 1999. 461-466.

Ariés, Philippe. Western Attitudes toward Death: From the Middle Ages to the Present. Baltimore and London: The Johns Hopkins University Press, 1977 (1974).

Bauman, Zygmunt. Mortality, Immortality and Other Life Strategies. Cambridge: Polity Press, 1992.

Bishop, Kyle. “The Sub-Subaltern Monster: Imperialist Hegemony and the Cinematic Voodoo Zombie". The Journal of American Culture, 2008 / 31:2. 141-152. 
Bordwell, David, Janet Staiger and Kristin Thompson. The Classical Hollywood Cinema. Film Style \& Mode of Production to 1960. London: Routledge, 1996 (1985).

Carroll, Noël. The Philosophy of Horror. New York and London: Routledge, 1990.

Cole, Phillip. "Rousseau and the Vampires: Toward a Political Philosophy of the Undead." The Undead and Philosophy: Chicken Soup for the Soulless. Ed. Richard Greene and K. Silem Mohammed. Chicago and La Salle: Open Court, 2006. 183-196.

Day, Jasmin. The Mummy's Curse: Mummymania in the English-speaking World. London and New York: Routledge, 2006.

Douglas, Mary. Purity and Danger. An Analysis of the Concepts of Pollution and Taboo. London and New York: Routlegde, 1996.

Dyer, Richard. White. London and New York: Routlegde, 1997.

Elias, Norbert. Kuolevien yksinäisyys (Über die Einsamkeit der Strebenden in unseren Tagen). Transl. Jari \& Paula Nieminen. Tampere: Gaudeamus, 1993.

Grant, Barry Keith. Film Genre: From Iconography to Ideology. London: Wallflower Papers, 2007.

Greene, Richard \& Mohammed, K. Silem. "(Un)dead (Un)certainties”. The Undead and Philosophy: Chicken Soup for the Soulless. Ed. Richard Greene and K. Silem Mohammed. Chicago and La Salle: Open Court, 2006. xiii-xvi.

Lowry, Edward \& deCordova, Richard 1984. "Enunciation and the Production of Horror in White Zombie". Planks of Reason. Essays on the Horror Film. Ed. Barry Keith Grant. Metuchen, N.J. and London: The Scarecrow Press Inc. 346-389.

Neale, Steve. Genre and Hollywood. London and New York: Routledge, 2000.

Phillips, Kendall R. Projected Fears. Horror Films and American Culture. Westport, Connecticut and London: Praeger, 2005. 
Saler, Benson and Charles A. Ziegler. "Dracula and Carmilla: Mythmaking and the Mind." Vampires. Myths \& Metaphors of Enduring Evil. Ed. Carla T. Kungl. Oxford: Inter-Disciplinary Press, 2003. 17-20.

Schatz, Thomas. Hollywood Genres: Formulas, Filmmaking, and the Studio System. New York: McGraw-Hill, 1981.

Sheller, Mimi. Consuming the Caribbean. From Arawaks to Zombies. London and New York: Routledge, 2003.

Shildrick, Margrit. Embodying the Monster. Encounters with the Vulnerable Self. London, Thousand Oaks and New Delhi: Sage Publications, 2002.

Walter, Tony. The Revival of Death. London and New York: Routledge, 1994.

Wood, Robin. "An Introduction to the American Horror Film". Planks of Reason. Essays on the Horror Film. Ed. Barry Keith Grant. Metuchen, N.J. and London: The Scarecrow Press Inc., 1984 (1979). 164-200.

[Received in 24/11/2011. Approved in 03/05/2012] 